\title{
Water Quality and Agricultural Sustainability in the Mantiqueira Ecological Corridor, Brazil
}

\author{
Gabriele Medeiros dos Santos ${ }^{1,2}$, Maria Leonor Ribeiro Casimiro Lopes-Assad1, \\ Marcos Cicarini Hott ${ }^{2 *}$, Marcelo Henrique Otenio ${ }^{2}$ \\ ${ }^{1}$ Universidade Federal de São Carlos, São Paulo, Brasil \\ ${ }^{2}$ Embrapa Gado de Leite, Juiz de Fora, Brasil \\ Email: marcelo.otenio@embrapa.br
}

Received 30 January 2014; revised 28 February 2014; accepted 21 March 2014

Copyright @ 2014 by authors and Scientific Research Publishing Inc.

This work is licensed under the Creative Commons Attribution International License (CC BY). http://creativecommons.org/licenses/by/4.0/

(c) (i) Open Access

\begin{abstract}
The presence of fecal coliforms is one of the determinants for classification of the quality of water bodies. The aim of this study was to evaluate the relationship between the water quality and surrounding land use in the area known as the Mantiqueira Ecological Corridor, which straddles the borders of the states of São Paulo, Rio de Janeiro and Minas Gerais, in Brazil. More particularly, we studied ten municipalities in Minas Gerais located in the region surrounding Serra do Papagaio State Park and Ibitipoca State Park. We established a classification of water bodies in the area surrounding the collection points in drainage basins based on the principles of sustainability. Using TM/Landsat 5 images, SPOTMap mosaics and the SRTM digital elevation model, we correlated land use classes with the environmental contamination index and topographic characteristics of the area studied. The presence of agriculture and urban areas heightened the differences in water quality classification in the comparison between the dry and rainy seasons, while in forested areas there was a greater equilibrium, with the same classification between the two seasons.
\end{abstract}

\section{Keywords}

Atlantic Forest, Water Body Classification, Land Use, Drainage Basin

\section{Introduction}

The need for monitoring water quality is set forth, in various important environmental regulatory documents [1].

*Corresponding author.

How to cite this paper: Santos, G.M., Lopes-Assad, M.L.R.C., Hott, M.C. and Otenio, M.H (2014) Water Quality and Agricultural Sustainability in the Mantiqueira Ecological Corridor, Brazil. Journal of Environmental Protection, 5, 500-508.

http://dx.doi.org/10.4236/jep.2014.56053 
In Brazil, the governmental body that sets standards and criteria related to the control and maintenance of environmental quality, with a perspective on the appropriate use of environmental resources, especially water, is the National Environmental Council (CONAMA), an advisory and deliberative agency chaired by the Minister of Environment.

The area of the Mantiqueira Mountain Range has a great economic and environmental importance [2]. The climatic characteristics of the region, with a positive annual water balance, make the region an important reference in water production, with high drainage potential and as a source for important rivers of Southeastern Brazil [3] [4]. The strategic location of the Mantiqueira Ecological Corridor brings strong pressure on the economy and occupation of the region. The main pressures on the environment are traditional forms of land management and use, with extensive grazing of livestock, burning of forest and planting in protected areas and on steep hillsides.

The adequate environmental management based on an approach that integrates the elements of the landscape can be facilitated by a monitoring network of environmental quality, especially of the water quality.

It is very important to obtain an understanding of rural reality, particularly in areas occupied mainly by people with less access to proper sanitation [5] and with cropping and stock breeding activities that can impair the water quality in headwaters areas. Environmental aspects are of keen interest to rural producers because their productivity depends on the integrity of the soil/water/plant/animal system.

The objective of this study was to analyze the water quality and its relationship with land use through a water quality index to estimate the impact of dairy cattle livestock on water quality.

\section{Methods}

\subsection{Study Area}

We selected 16 communities in nine municipalities (Lima Duarte, Santana do Garambéu, Santa Rita de Ibitipoca, Pedro Teixeira, Olaria, Ibertioga, Carvalhos, Bocaina de Minas and Alagoa) (Figure 1) where dairy production by smallholders is the main activity generating employment and income, along with Quilombola ${ }^{1}$ Colônia do-

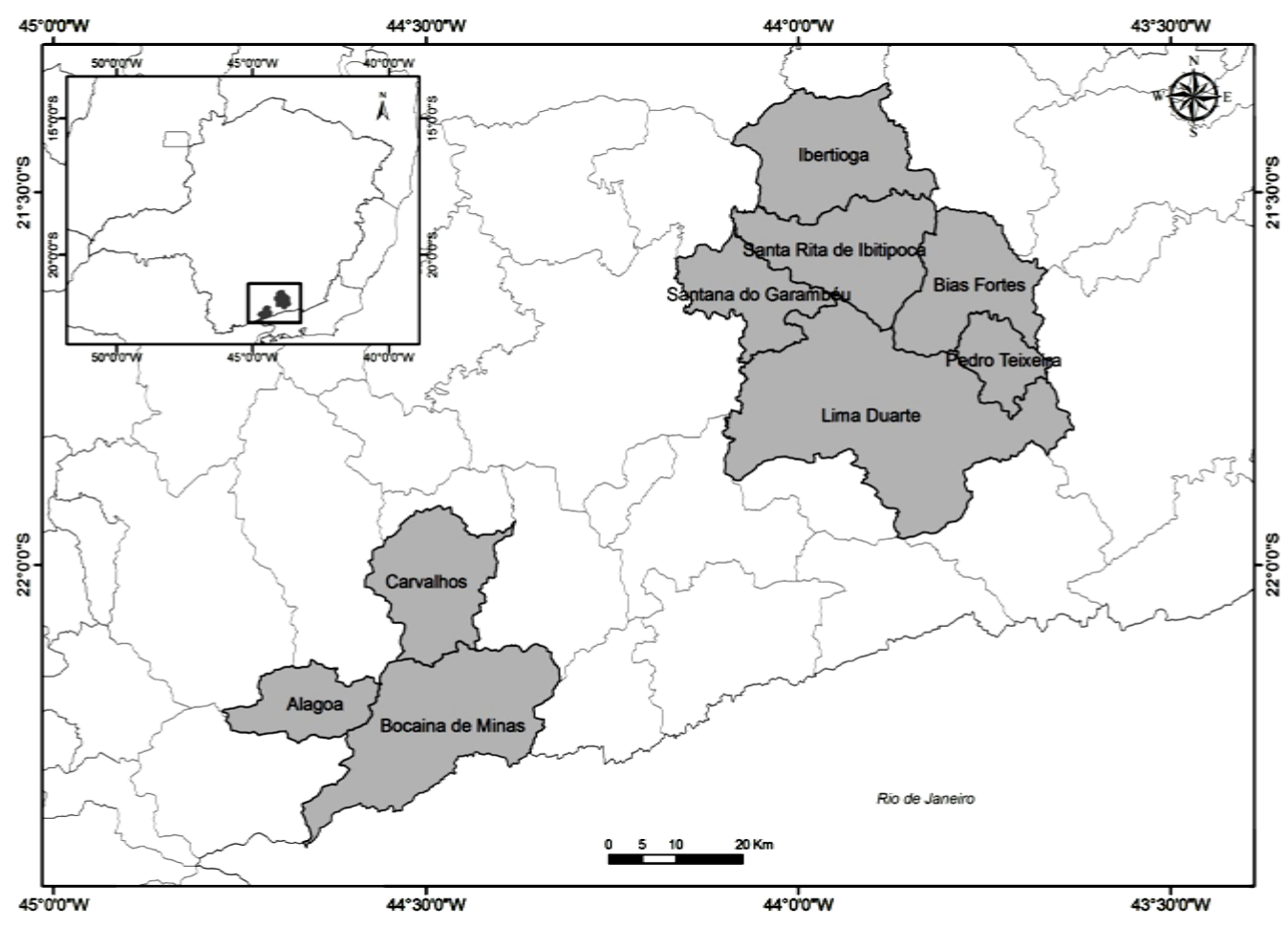

Figure 1. Area of the municipalities studied.

${ }^{1}$ Quilombolas are groups formed mostly by rural or urban black populations, defined by the relationships with the land, kinship, territory, ancestry, traditions and cultural practices themselves. It is estimated that across the country there are more than three thousand quilombolas communities [6]. 
Paiol, in the municipality of Bias Fortes. Of the ten municipalities selected, seven are in the area around Ibitipoca State Park and the other three are in the Mantiqueira II Nucleus of the Mantiqueira Ecological Corridor.

All the municipalities are in southeastern Minas Gerais and are distributed in two drainage basins: the Alto Rio Grande and Paraíba do Sul.

\subsection{Water Analyzis}

The water samples were collected and analyzed by 17 youths, one from each community, chosen and trained by the Embrapa Dairy Cattle Research Unit (Embrapa Gado de Leite). The samples were collected once every 15 days from June 2009 to June 2010, and the parameters analyzed were those specified by CONAMA Resolution $357 / 2005$, which classifies natural water bodies by their preponderant use. The parameters analyzed were concentrations of fecal coliform, total coliform, Salmonella, phosphate, ammonia, iron, chloride, nitrate and nitrite, dissolved oxygen, $\mathrm{pH}$, turbidity, hardness and temperature, using water taken from lotic water bodies (rivers and streams), according to the method described by [4] [7]. These analyses were done in the field with portable kits, named Tecnobac ${ }^{\circledR}$ (for microbiological parameters), Cardkit ${ }^{\circledR}$ (nitrate and nitrite) and Ecokit ${ }^{\circledR}$ (the others), produced and marketed in Brazil by Alfakit.

\subsection{Validation of the Analyses and Georeferencing}

The accuracy of water analyses performed on 17 points with portable kits was verified by a comparison with measurements of the same parameters made with a multiparameter Hanna (HI 9828 model) manufactered by Hanna Instruments. These measures were done during the visit to each community and sampling point. The points' coordinates were also determined by the Global Positioning System with a GPS locator, from Garmim Ltd.

\subsection{Digital Processing of Images}

The evaluation of land use in the study area was performed by Landsat/TM and SPOT satellite images. We obtained two TM/Landsat 5 images (Figure 2) from the National Space Research Institute (INPE) [8], from satel-

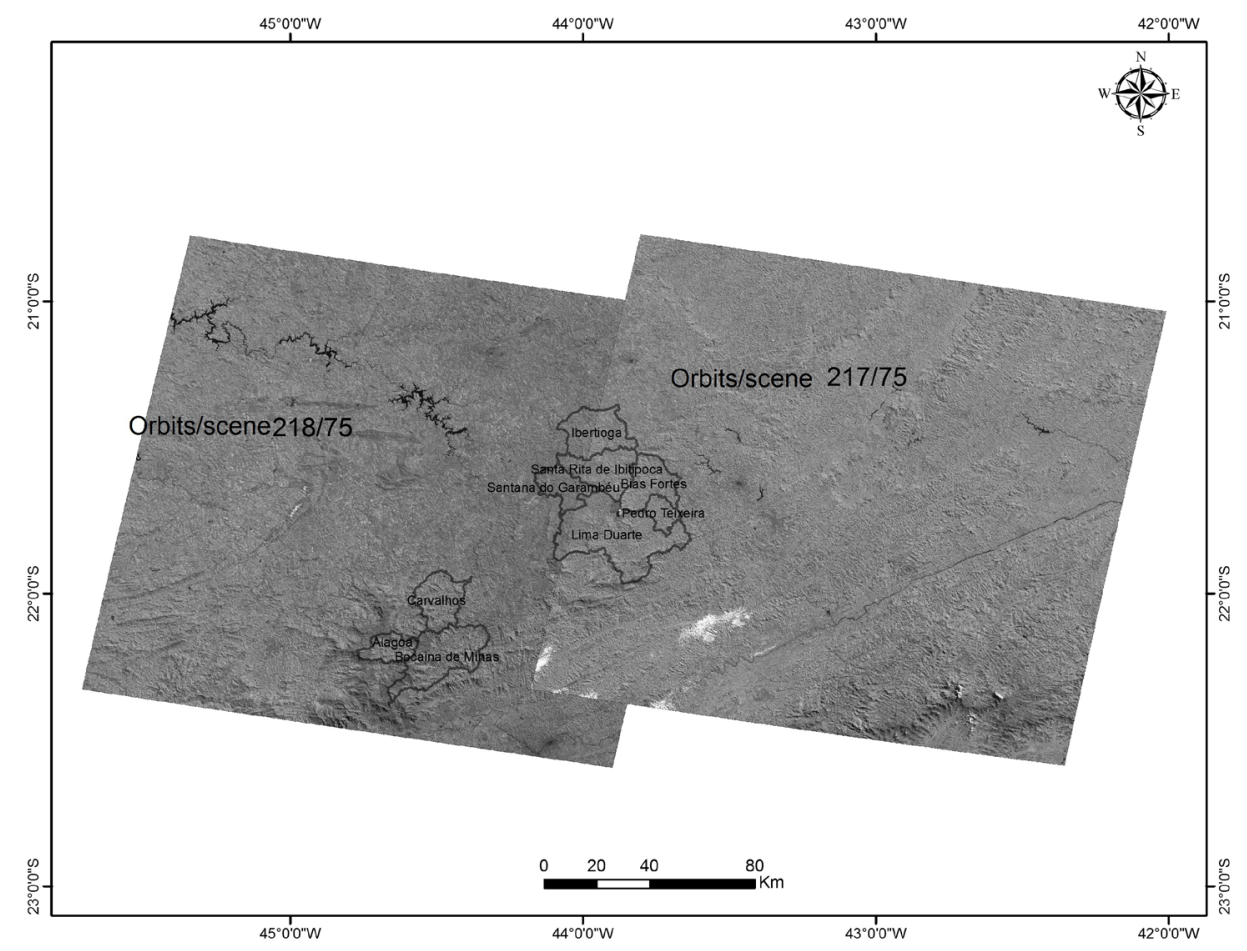

Figure 2. Georeferencing of scenes 217/75 and 218/75 from 2010, obtained from the TM/ LANDSAT 5 database for the study area. Source: [8]. 
lites with orbits 217 (scene 75) and 218 (scene 75), in cartographic scale of 1:150,000. We also used ten extracts from the SPOTMap mosaic, with a resolution of $2.5 \mathrm{~m}$, to study each of the image analysis criteria (Table 1), seeking to correlate them with the contamination in the sampled watercourse. The false-color images were obtained by red and near and medium infrared bands, utilized for supervised classification. The geoprocessing was done with ArcGis, version 9.3, from the Environmental Systems Research Institute (ESRI).

In data processing, we carried out visual joining of consecutive images by equalization, altering the distribution of the pixel values in the histogram of each band in both images, to promote similarity between them (Figure 3). Then we obtained the control points from the high-resolution SPOTMap mosaic extracts and orthoreferenced Landsat 7 images, for processing of the Landsat 5 images, which covered the areas of the collection points. We georeferenced the images to obtain a square error of at most one pixel (wich is the acceptable limit for a final scale of 1:250,000), resulting from the MDE/SRTM, for the total area, determining the derivation of the catchment basins upstream of the sampling point.

To identify the land use classes we used supervised classification by the maximum likelihood method, according to [9]. In this way, by using the training samples, we managed to identify and classify the areas into groups according to land use and plant cover (Figure 3).

The classes adopted are shown in Table 1 . The software automatically associates each pixel with a class ac-

(A)

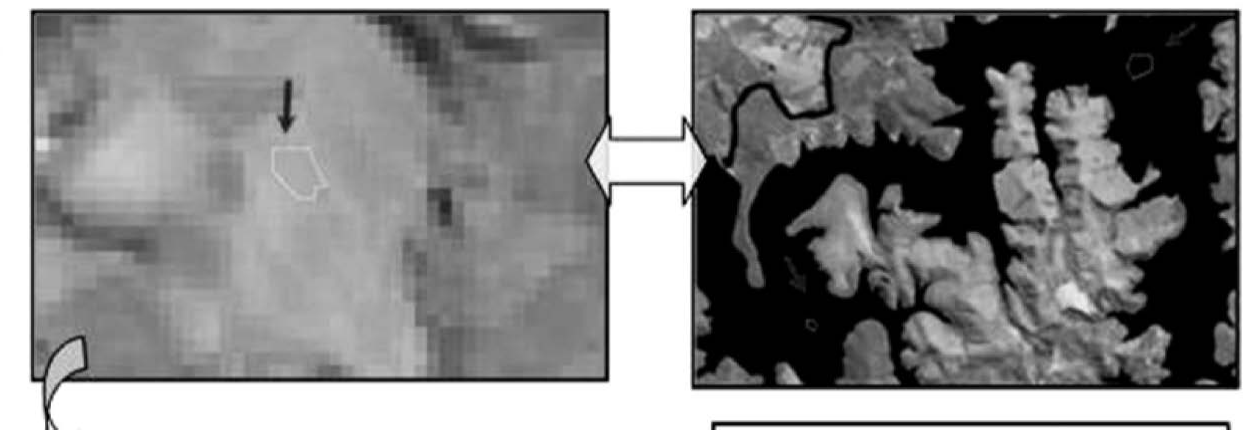

(C)

\section{(B)}

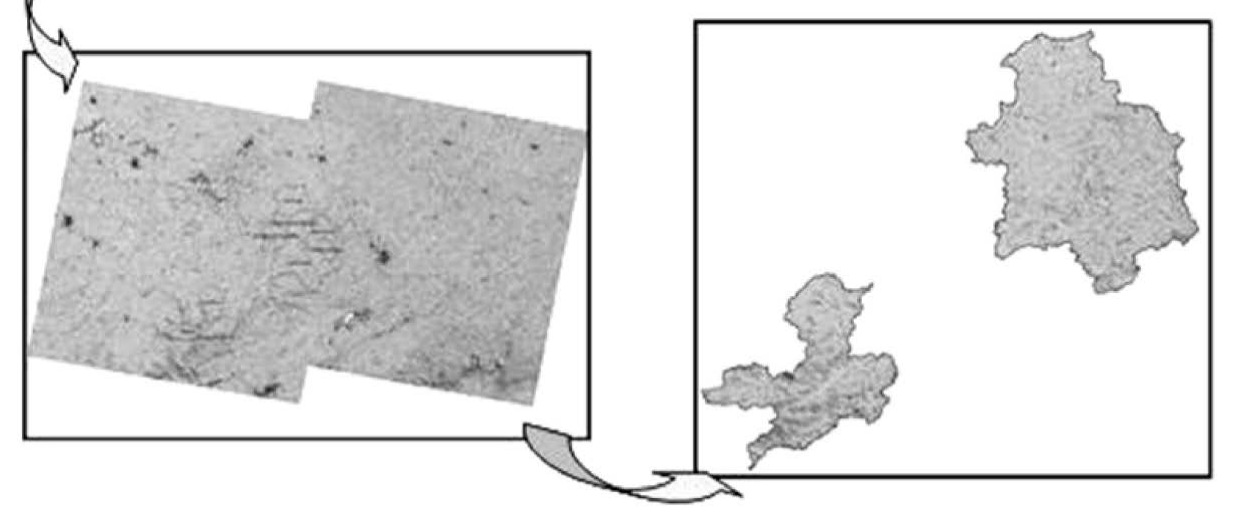

(D)

Figure 3. Representation of the process for identifying classes by the maximum likelihood method. (A) and (C) Extraction of polygons representing water and forest classes, respectively; (B) Mosaic classified by the land use classes; (D) Study area extracted and classified by land use.

Table 1. Types of cover and their characteristics.

\begin{tabular}{cc}
\hline \multicolumn{1}{c}{ Class } & Description \\
\hline $\begin{array}{c}\text { Urban area/Exposed soil } \\
\text { Agricultural area }\end{array}$ & $\begin{array}{c}\text { Areas with or without structures where all the plant cover has been removed. } \\
\text { Forest }\end{array}$ \\
Composed mainly of herbaceous or shrub vegetation, notably natural or planted pastures. \\
Formations of dense forest interspersed with small clearings as well as \\
seasonal or semideciduous forest fragments. \\
Whers \\
Watercourses or lakes. \\
Shadows and clouds.
\end{tabular}


cording to the similarity statistics obtained in each spectral signature, generating a thematic map with the previously specified classes.

The types of cover were visually classified by colors of the composition of RGB bands of each image, according to [10], to obtain a single base with physical continuity.

Then we performed hydrological modeling, which allowed identification of the geomorphometric characteristics of the basin under study. We did this in five steps (Figure 4), for which we generated the following information planes (IPs) for derivation of the catchment basins upstream of the water collection points: a) drainage flow direction IP; b) accumulated flow IP; c) drainage network IP; d) catchment basin IP; and e) mouth IP (identification of the point with greatest accumulated flow in the drainage nearest to the collection point, in a radius of $300 \mathrm{~m}$ ).

We considered the mouth to be the point that receives the flow equivalent to the watercourse that passes by the collection point. This was determined from the basin's mouth, within a 300-meter radius, equivalent to the collection points, whose coordinates were obtained by GPS. From these data, it was possible to produce a contamination risk model in function of the catchment basin, land use and distance to the outlet in the drainage area equivalent to the collection point, whose coordinates were obtained by GPS (Figure 5).
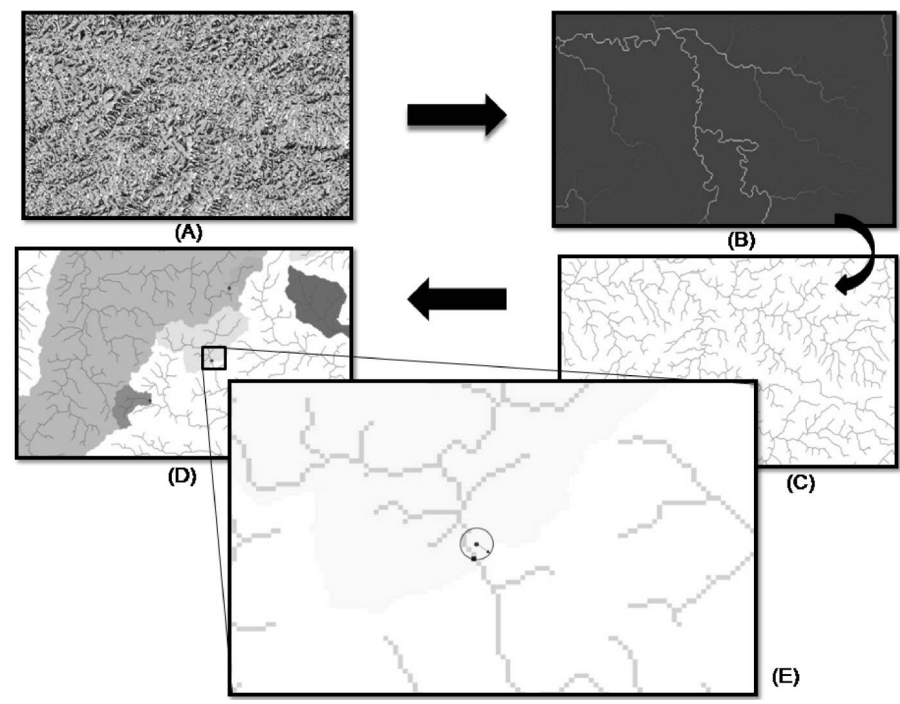

Figure 4. Phases of the hydrological modeling.

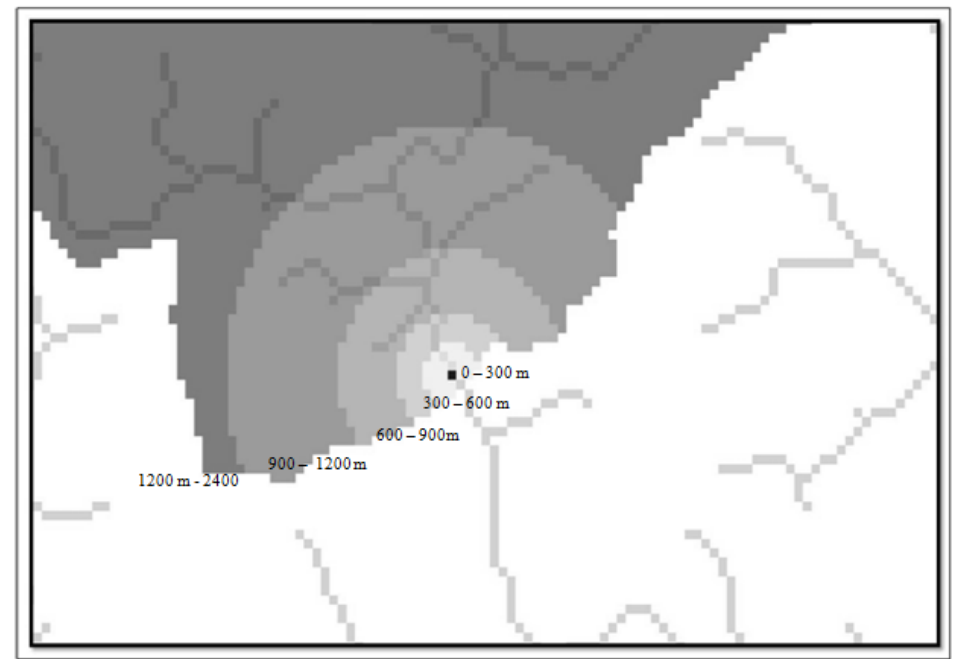

Figure 5. Representation of the contamination risk gradient in function of distance to the collection point. 


\section{Results and Discussion}

From the Land Use and Cover Map for 2010 (Figure 6) it was possible to confirm the predominance of forest and agricultural areas in the study region.

The average values of parameters measured in the field are grouped in the Table 2 for rainy season (from October 2009 to March 2010) and in Table 3 for the dry season (from June to September 2009). Both table also

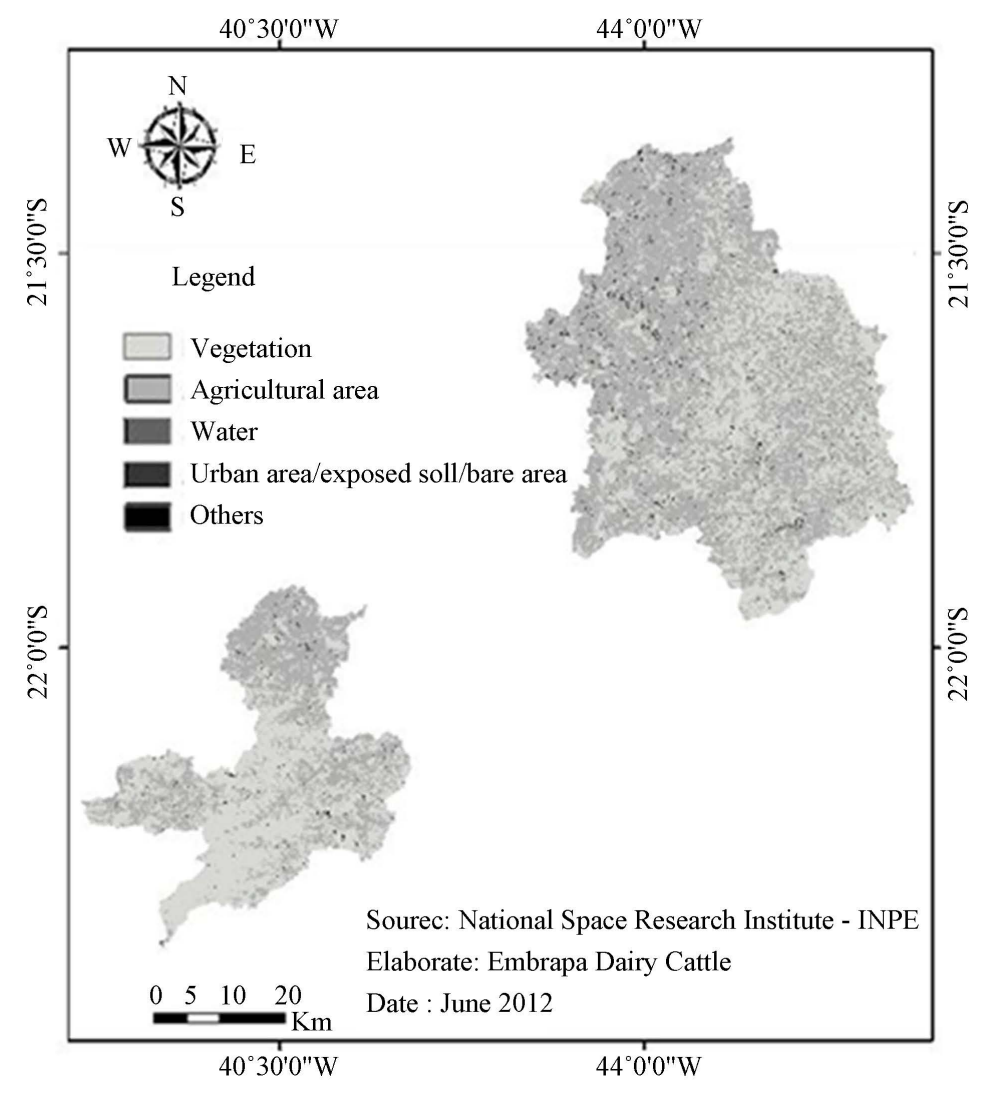

Figure 6. Thematic map of land use and cover in the areas studied.

Table 2. Mean of the water analyses and classification by point in the dry season (April 2010 to August 2010).

\begin{tabular}{cccccccccccccccccc}
\hline Parameters/Point & $\mathbf{1}$ & $\mathbf{2}$ & $\mathbf{3}$ & $\mathbf{4}$ & $\mathbf{5}$ & $\mathbf{6}$ & $\mathbf{7}$ & $\mathbf{8}$ & $\mathbf{9}$ & $\mathbf{1 0}$ & $\mathbf{1 1}$ & $\mathbf{1 2}$ & $\mathbf{1 3}$ & $\mathbf{1 4}$ & $\mathbf{1 5}$ & $\mathbf{1 6}$ & $\mathbf{1 7}$ \\
\hline Fecal Coliform Count (UFC100/mL) & 465 & 943 & 435 & 210 & 640 & 330 & 840 & 480 & 648 & 1120 & 37.420 & 599.5 & 326 & 493 & 1.260 & 840 & 645 \\
Total Colony Forming Units (CFU100/mL) & 1.3 & 1.6 & 29.8 & 780 & 1.4 & 840 & 18.2 & 1.3 & 5.4 & 3.3 & 8.6 & 40.9 & 16.4 & 8.3 & 15.4 & 4.8 & 1415 \\
Salmonella (UFC/100 mL) & 0 & 0 & 0 & 0 & 500 & 90 & 270 & 253 & 0 & 0 & 0 & 0 & 0 & 0 & 210 & 177 & 720 \\
Classification & $\mathbf{2}$ & $\mathbf{2}$ & $\mathbf{2}$ & $\mathbf{2}$ & $\mathbf{2}$ & $\mathbf{2}$ & $\mathbf{2}$ & $\mathbf{2}$ & $\mathbf{2}$ & $\mathbf{3}$ & $\mathbf{3}$ & $\mathbf{2}$ & $\mathbf{2}$ & $\mathbf{2}$ & $\mathbf{3}$ & $\mathbf{2}$ & $\mathbf{2}$ \\
\hline
\end{tabular}

Table 3. Mean of the water analyses and classification by point in the rainy season (October 2009 to March 2010).

\begin{tabular}{|c|c|c|c|c|c|c|c|c|c|c|c|c|c|c|c|c|c|}
\hline Parameters/Point & 1 & 2 & 3 & 4 & 5 & 6 & 7 & 8 & 9 & 10 & 11 & 12 & 13 & 14 & 15 & 16 & 17 \\
\hline Fecal Coliform Count (CFU100/mL) & 744 & 1.0 & 379.8 & 312 & 480 & 375 & 1.1 & 580 & 3.4 & 1.04 & 465 & 610 & 532 & 820 & 1.5 & 480 & 700 \\
\hline Total Colony Forming Units (CFU100/mL) & 1.4 & 1.67 & 537.6 & 1.0 & 760 & 900 & 17.2 & 1.6 & 4.72 & 2.25 & 5.2 & 10.6 & 14.3 & 3.7 & 13.1 & 1.2 & 1.6 \\
\hline Salmonella (CFU/100 mL) & 0 & 360 & 0 & 120 & 0 & 450 & 60 & 343.3 & 0 & 0 & 0 & 0 & 0 & 1.060 & 286.6 & 90 & 633.3 \\
\hline Classification & 2 & 2 & 3 & 2 & 2 & 2 & 3 & 2 & 2 & 3 & 3 & 2 & 2 & 2 & 3 & 2 & 3 \\
\hline
\end{tabular}


present the classification of each collection point in each season, classified according to CONAMA Resolution 357/05 [11].

A study defining a water quality index to characterize the Mantiqueira Range region by Principal Component Analysis showed that indicators with greatest weight were total coliform, nitrate, fecal coliform, chemical oxygen demand and temperature [2]. In this work, we present only the data on fecal coliforms, total coliforms and Salmonella, which are considered to be the most decisive factors regarding microbiological contamination of a drainage basin.

In the rainy season (summer), points 3, 7 and 17 are in class 3 and the others are in class 2, while in the dry season (winter), points 10 and 11 are in class 3 and the others in class 2. The presence of fecal coliforms at some points implies a change in water quality classification, according to the limits established by CONAMA Resolution 357/2005 [11] (Table 2 and Table 3).

These results confirm that pollution occurs in the study area in diffuse form, with small variations regarding the presence or absence of Salmonella, and indicate contamination at these points with human feces, which can make the water unfit for dairy farming and human consumption according to the season [12].

Comparing Table 2 and Table 3, it was found that points 1, 2, 4, 5, 6, 8, 9, 12, 13, 14 and 16 kept their qualitative characteristics, remaining in class 2 in the dry season and in the rainy season. These points have riparian vegetation along the riverbanks, with patches of forest in the hill areas. The vegetation prevents soil erosion and sediment transport to streams, reducing bank erosion. These points are far from the urban areas and are not subject to high loads of urban sewage (Table 4).

The inadequate management of the agricultural areas around the sample points aggravates the impact of agricultural activities on the water resources in the region. The uneven terrain and extensive grazing system in the region makes farmers exploit small areas in low-lying valleys, where they are flatter. The exploitation of areas near watercourses should be avoided, especially by limiting access of animals that cause trampling on river banks, as observed during the field visits, causing bank erosion.

The spatial variability of the rate of water infiltration in the soil, to determine the risk of contamination, is useful for the sustainable management of rangelands [13]. The high fecal coliform values found in this study indicate contamination by feces, and consequently the presence of pathogenic microorganisms [14]. These coliforms can originate from various sources, such as domestic untreated sewage, livestock waste or agricultural industries.

The determination of the coliforms concentration is an important parameter and should be the focus of action to improve the environmental quality of these areas. Actions to improve sanitation and restore riparian vegetation and vegetation cover on the hilltops have been proven effective in maintaining and restoring the quality of water resources affected by human activities [15]. The data collected in the evaluated points and the generated images indicated that plant cover prevents the intense flow and the consequent transport of sediment and waste of agricultural activities, reducing siltation and contamination of rivers and streams.

In the study area, the traditional practices of agriculture and livestock involve deforestation by fire and the use of areas of bottom of valleys for planting and grazing animals. This explains the results obtained in the analyzed points, where the change of classification in the rainy season reveals that the surrounding areas have been constantly impacted by inadequate management of the land, water and plants.

The concentration of fecal coliforms in the sampled points depended on the geographical location of each point, as shown in image analysis. The effects of the presence of pollution sources at higher elevations in the catchment areas around each point were higher in areas with intense agricultural activity and urbanization than in those with greater forest cover. Consequently, in those areas there was a greater change in the classification of water quality between the dry and rainy seasons, in contrast to the observed balance between the two stations in the forest areas.

\section{Summary}

The currently prevailing model of agricultural development can cause degradation of soil and water, desertification, soil salinization, biodiversity reduction and ecological imbalances. These impacts are unsustainable. The analyses of catchment basins regarding water quality with the use of geoprocessing, remote sensing and water monitoring provide an overview of the factors that contribute to contamination. The results of this work show that the study area has significant percentages of three classes of land occupation: agricultural and forested areas 
Table 4. Contamination risk gradient-percentage of land use classes by distance for each point.

\begin{tabular}{|c|c|c|c|c|c|c|c|c|c|c|c|c|c|c|c|c|c|c|c|}
\hline \multirow[b]{2}{*}{$\begin{array}{l}\vec{\Xi} \\
\stackrel{0}{0}\end{array}$} & \multicolumn{3}{|c|}{$(0-300) \mathrm{m}$} & \multicolumn{4}{|c|}{$(300-600) m$} & \multicolumn{4}{|c|}{$(600-1200) m$} & \multicolumn{4}{|c|}{$(1200-2400) m$} & \multicolumn{4}{|c|}{$(>2400) \mathrm{m}$} \\
\hline & 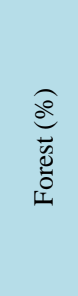 & 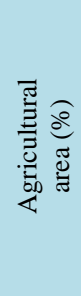 & 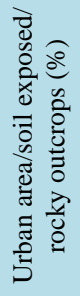 & 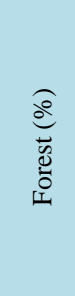 & 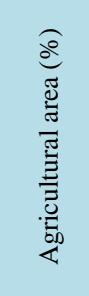 & 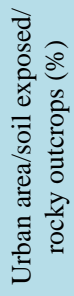 & 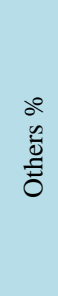 & 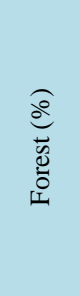 & 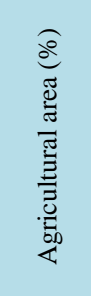 & 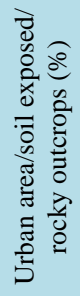 & 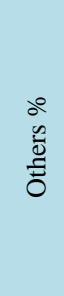 & 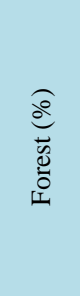 & 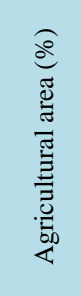 & 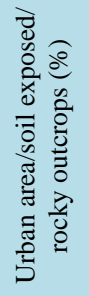 & 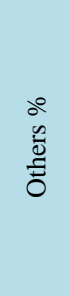 & 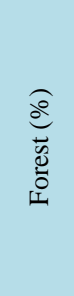 & 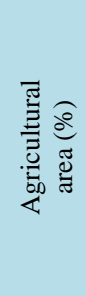 & 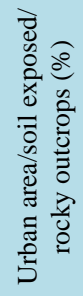 & 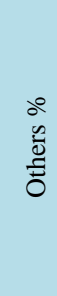 \\
\hline 1 & 0.05 & 0.37 & & 0.29 & 0.58 & & & 0.68 & 2.05 & 0.06 & & 0.95 & 5.50 & 0.02 & & 48.27 & 37.66 & 3.10 & 0.41 \\
\hline 2 & 0.31 & 0.33 & & 0.77 & 0.52 & & & 2.53 & 2.83 & 0.02 & & 8.73 & 12.56 & 0.12 & 0.06 & 40.13 & 30.76 & 0.33 & 0.01 \\
\hline 3 & 1.19 & 0.89 & 0.11 & 1.53 & 0.98 & & & 7.45 & 3.94 & 0.06 & & 16.16 & 16.40 & 0.16 & & 34.86 & 14.46 & 1.81 & 0.01 \\
\hline 4 & 0.16 & 1.22 & & 0.66 & 2.06 & 0.05 & & 3.61 & 6.24 & 0.06 & & 6.82 & 16.34 & 0.16 & & 14.58 & 45.88 & 0.27 & \\
\hline 5 & 10.62 & 1.55 & & 13.42 & 5.63 & & & 39.64 & 18.03 & & & 5.00 & 6.12 & & & & & & \\
\hline 6 & 1.76 & 6.39 & 0.74 & 7.24 & 14.57 & 0.20 & & 16.18 & 14.98 & 0.11 & & 28.71 & 9.06 & 0.07 & & & & & \\
\hline 7 & 0.03 & 0.33 & & 0.10 & 0.52 & & & 1.51 & 1.18 & 0.03 & & 4.52 & 7.01 & 0.12 & & 50.03 & 33.97 & 0.64 & 0.01 \\
\hline 8 & 0.34 & 0.47 & & 0.17 & 0.86 & 0.01 & & 1.78 & 5.80 & 0.11 & & 12.98 & 24.58 & 0.30 & 0.01 & 29.74 & 22.55 & 0.29 & 0.01 \\
\hline 9 & 0.55 & 0.56 & & 0.84 & 2.00 & 0.09 & & 3.89 & 6.12 & 0.05 & & 16.55 & 16.37 & 0.21 & 0.06 & 33.02 & 19.46 & 0.21 & 0.03 \\
\hline 10 & 0.1 & 0.1 & & 0.07 & 2.05 & 0.03 & & 0.2 & 0.8 & 0.03 & & 1.2 & 2.8 & 0.09 & & 32.4 & 60.07 & 1.59 & 0.01 \\
\hline 11 & 0.08 & 0.83 & & 2.87 & 2.42 & & & 1.26 & 8.01 & 0.31 & & 4.87 & 26.39 & 0.48 & & 12.96 & 42.16 & 0.50 & \\
\hline 12 & 0.51 & 1.56 & & 31.59 & 32.04 & & & 10.49 & 3.29 & 0.12 & & 19.16 & 9.94 & 0.25 & & 17.79 & 31.29 & 0.29 & \\
\hline 13 & 9.13 & 16.32 & & 0.36 & 0.43 & & & 2.63 & 8.28 & & & & & & & & & & \\
\hline 14 & 0.12 & 0.22 & & 7.86 & 5.26 & 0.01 & & 2.11 & 1.54 & & & 8.55 & 3.41 & & 0.02 & 73.79 & 8.48 & 0.01 & 0.13 \\
\hline 15 & 2.40 & 2.53 & 0.03 & 9.72 & 7.26 & & 0.40 & 25.70 & 20.41 & 0.14 & & 14.57 & 21.05 & 0.04 & & & & & \\
\hline 16 & 1.86 & 4.52 & & 18.15 & 13.20 & & & 25.48 & 9.57 & & 0.05 & 28.44 & 10.93 & 0.51 & 1.25 & & & & \\
\hline 17 & 4.15 & 6.30 & & 0.07 & 2.05 & 0.03 & & 20.05 & 38.03 & 0.13 & & & & & & & & & \\
\hline
\end{tabular}

and water bodies. The relative proportion of these three areas confirms that farming and stock breeding are the main economic activities in the region and are a source of degradation of the natural vegetation cover. The alteration of the water quality classification of the studied points indicates a diffuse pollution. The proposal to relate the water resource classification and its seasonal variation with satellite images of the catchment basins allowed an analytic and visual correlation between the impact of agricultural activity and the water quality.

\section{Acknowledgements}

The authors gratefully acknowledge the Brazilian Agricultural Research Corporation, the National Council for Scientific and Technological Development and the Agency of Minas Gerais Research Foundation, for supporting this study.

\section{References}

[1] Finotti, A.R., Finkler, R., Silva, M.A. and Cemin, G. (2009) Monitoramento de recursos hídricos em áreas urbanas. Educs, Caxias do Sul.

[2] Pinto, L.C., de Mello, C.R., Ferreira, D.F. and Ávila, L.F. (2013) Water Quality Index in Two Land Use Situations in the Mantiqueira Range. Ciência Agrotécnica, 37, 338-342. 
[3] de Menezes, M.D., Junqueira Júnior, J.A., de Mello, C.R., da Silva, A.M., Curi, N. and Marques, J.J. (2009) Dinâmica hidrológica de duas nascentes, associada ao uso do solo, características pedológicas e atributos físico-hídricos na sub-bacia hidrográfica do Ribeirão Lavrinha—Serra da Mantiqueira (MG). Scientia Forestalis, 37, 175-184.

[4] Mello, C.R., Viola, M.R., Norton, L.D., Silva, A.M., Weimar, F.A. (2008) Development and Application of a Simple Hydrologic Model Simulation for a Brazilian Headwater Basin. Catena, 75, 235-247.

[5] Amaral, L.A., Nader Filho, A., Rossi Junior, O.D., Ferreira, L.A.F. and Barros, L.A.F. (2003) Água de consumo humano com fator de risco à saúde em propriedades rurais. Revista de Saúde Pública, 37, 510-514. http://dx.doi.org/10.1590/S0034-89102003000400017

[6] Brasil (2003) Decreto No. 4.887. http://www.planalto.gov.br/ccivil_03/decreto/2003/d4887.htm

[7] Hermes, L.C., Fay, E.F., Buschinelli, C.C.A., Silva, A.S. and Silva, Ê.F.F. (2004) Participação comunitária em monitoramento da qualidade da água. Embrapa: CNPMA, Circular Técnica, No. 8. Jaguariúna, Brasil.

[8] INPE, Instituto Nacional de Pesquisas Espaciais (2008) Catálogo de imagens CBERS. http://www.dgi.inpe.br/CDSR

[9] Jensen, J.R. (2009) Sensoriamento remoto do ambiente: uma perspectiva em recursos terrestres. Tradução (INPE): Epiphanio, J.C.N., Formaggio, A.R., Santos, A.R., Rudorff, B.F.T., Almeida, C.M., Galvão, L.S., São José dos Campos: Parêntese.

[10] Gonzalez, R., Woods, R.E. (2000) Processamento de Imagens Digitais. Ed. Edgard Blucher Ltda. São Paulo.

[11] Brasil. Conselho Nacional do Meio Ambiente. “Resolução No. 357”, 17 de março de 2005. Diário Oficial da União, 2005. http://www.mma.gov.br/port/conama/res/res05/res35705.pdf

[12] Amaral, G.F. (2007) Análise do segmento de trutas: abordagens de cadeia produtiva e turismo rural. M.Sc. Thesis, Universidade Federal Rural do Rio de Janeiro, Rio de Janeiro.

[13] Miguel, F.R.M., Vieira, S.R., Grego, C.R. (2009) Variabilidade espacial da infiltração de água em solo sob pastagem em função da intensidade de pisoteio. Pesquisa Agropecuária Brasileira, 44, 1513-1519. http://dx.doi.org/10.1590/S0100-204X2009001100020

[14] Silva, R.C.A., Araujo, T.M. (2003) Qualidade da água do manancial subterrâneo em áreas urbanas de Feira de Santana (BA). Ciência \& Saúde Coletiva, 8, 1019-1028. http://dx.doi.org/10.1590/S1413-81232003000400023

[15] Pereira-Silva, E.F.L., Pires, J.S.R, Hardt, E., Santos, J.E. and Ferreira, W.A. (2011) Avaliação da qualidade da água em microbacias hidrográficas de uma Unidade de Conservação do Nordeste do estado de São Paulo, Brasil. Revista Brasileira de Biociência, 9, 371-381. 